\title{
Schroth treatment results in AIS at high risk for surgery - 2 case studies
}

\author{
Lior Neuhaus Sulam*, Iris Braz \\ From 11th International Conference on Conservative Management of Spinal Deformities - SOSORT 2014 \\ Annual Meeting \\ Wiesbaden, Germany. 8-10 May 2014
}

Scoliosis is a 3D deformity of the spine combined with pathological structural changes.

Scoliosis tend to progress through growth.

BSPTS method based on Schroth principles is a specific physiotherapeutic treatment method for scoliosis. It considers the $3 \mathrm{~d}$ changes of the spine, the geometrical and axial torsion of the hole spine, thorax and pelvic. Using specific exercise to achieve better muscle balance and corrected posture in order to prevent progression, improve esthetic and function.

\section{Aims}

To present the efficacy of the BSPTS method based on Schroth principles treating progressive moderate AIS in 2 case studies using objective measures.

\section{Case 1}

Starting point- age 17.5 years, Risser $=2+$, Rt thoracolumbar L3-T7 $52^{\circ}$ cobb, Trace 10/11, scoliometer $16^{\circ} \mathrm{rt}$ hump, plumb line $2.5 \mathrm{~cm}$ rt from center of sacrum.

End point- age 19, Risser $=4$, Rt thoracolumbar L3T7 $35^{\circ} \mathrm{cobb}$, Trace $6 / 11$, scoliometer $12^{\circ} \mathrm{rt}$ hump, plumb line $1 \mathrm{~cm}$ rt from center of sacrum.

\section{Case 2}

Starting point- age 14.5 years, Risser $=1$, Rt Tx $53^{\circ}$ cobb, Trace 9/11, scoliometer $17^{\circ} \mathrm{rt}$ hump, plumb line $2 \mathrm{~cm}$ rt from center of sacrum.

End point- age 15.9, Risser $=3 \mathrm{Rt} \mathrm{Tx} 30^{\circ} \mathrm{cobb}$, Trace 5/ 11 , scoliometer $9^{\circ} \mathrm{rt} \mathrm{hump,} \mathrm{plumb} \mathrm{line} 1 \mathrm{~cm}$ rt from center of sacrum.

\section{Conclusions}

In spite of the late diagnosed moderate AIS the combined treatment of specific intensive physiotherapy and RSC brace achieved improved Cobb angel, better esthetic and the operation was avoided.

\section{Implications}

Early detection could improve the results in all parameters, school screening or other systematic method for early detection is highly recommended

Specialized team work of scoliosis rehabilitation Orthopedic physician, Orthotist, Physiotherapist, and compliant patient can achieve better result even in moderate-severe cases.

Published: 4 December 2014

doi:10.1186/1748-7161-9-S1-O48

Cite this article as: Sulam and Braz: Schroth treatment results in AIS at high risk for surgery - 2 case studies. Scoliosis 2014 9(Suppl 1):O48.

Submit your next manuscript to BioMed Central and take full advantage of:

- Convenient online submission

- Thorough peer review

- No space constraints or color figure charges

- Immediate publication on acceptance

- Inclusion in PubMed, CAS, Scopus and Google Scholar

- Research which is freely available for redistribution

Submit your manuscript at www.biomedcentral.com/submit 